\title{
Violence and narrative: structural and interpersonal violence in contemporary French literature
}

\author{
Marieke Mueller
}

Abstract: This article considers the representation of violence in contemporary French literature, highlighting the way in which texts combine sociological and narrative strategies. It focuses on two internationally acclaimed texts, Didier Eribon's Returning to Reims (2009) and Édouard Louis's History of Violence (2016). It examines the narrativisation of incidents of interpersonal violence and trauma in each text, and interrogates the specific ways in which such examples are embedded in a sociological understanding of structural violence indebted to Pierre Bourdieu. By examining the interrelatedness of different forms of violence, as well as the specific function of narrative, the article seeks to contribute to an interdisciplinary perspective that highlights the dialogue between literary studies and its sub-discipline of narratology on the one hand, and sociology on the other.

Keywords: Structural violence, interpersonal violence, narrative, contemporary French literature, Bourdieu, Eribon, Louis.

Note on the author: Marieke Mueller is a Lecturer in French at Aberystwyth University. She previously completed her DPhil at Oxford University, and taught at King's College London and in Paris. Her research area is modern and contemporary French and francophone literature and philosophy, with a focus on existentialism, sociology, contemporary fiction, and women's writing. Her current research project examines the relationship between narrative and violence, and she has published on conceptions of violence in Jean-Paul Sartre and Pierre Bourdieu.

mam139@aber.ac.uk.

(C) The author(s) 2020. This is an open access article licensed under a

Creative Commons Attribution-NonCommercial-NoDerivs 4.0 Unported License 
Throughout the 20th century, French literature was often profoundly marked by the coming together of theory and fiction. Authors like Jean-Paul Sartre and Simone de Beauvoir, for example, frequently mobilised their fictional texts in order to develop philosophical arguments through the vehicle of narrative. At the same time, the literary productions by the Surrealists were often embedded within a wider artistic and political framework. Very recently, this convergence between theory and fiction has taken a remarkable turn, with the rise to prominence of a group of Frenchlanguage writers whose work is heavily indebted to sociology, in particular to the writings of Pierre Bourdieu. ${ }^{1}$ This group includes, amongst others, Didier Eribon and Édouard Louis, who are now widely read on an international level. Didier Eribon's Retour à Reims [Returning to Reims] (2009) has seen particular international success in Germany and its dramatisation was presented to the British public at the Manchester International Festival in 2017. Édouard Louis's The End of Eddy (2015) has been extensively reviewed in the American and British press and has been translated into over twenty languages. ${ }^{2}$

Both authors have recently produced (semi-)autobiographic texts that portray their trajectories as what Eribon calls 'class defectors'. The texts revolve around the theme of the respective narrators' rural or small-town working-class roots and their subsequent social ascendency through entering the Parisian intellectual milieu. Their fiction is informed in particular by theories of symbolic and structural violence, and simultaneously presents accounts of incidents of interpersonal violence, such as discrimination, physical and emotional abuse, and homophobia. In the following, the focus will be on two texts in particular, Eribon's Returning to Reims and Édouard Louis's Histoire de la violence (2016), an auto-fictional account of the traumatic experience of rape. I will examine the narrativisation of incidents of interpersonal violence and trauma in each text, and interrogate the specific ways in which such examples are embedded in a sociological understanding of structural violence. ${ }^{3}$ By examining the interrelatedness of different forms of violence, as well as the specific function of narrative, I aim to contribute to an interdisciplinary perspective that highlights a fruitful contemporary dialogue between literary studies and its sub-discipline of narratology on the one hand, and sociology on the other.

\footnotetext{
${ }^{1}$ And, especially in the case of Eribon, to the work of Michel Foucault.

${ }^{2}$ See, for example: Bartlett (2017).

${ }^{3}$ Both authors use the term 'violence' to designate both physical attacks and verbal outbursts, and even a certain attitude or state of mind. In the following this broad understanding of violence will be applied.
} 


\section{RETURNING TO REIMS}

In Eribon's Retour à Reims, the author presents an autobiographical account of a return journey to his native Reims in the north-east of France, after a long absence followed by his father's death. Into this framework, which situates the narrative voice at a distance from the family milieu, are embedded episodes describing scenes from the past, as well as socio-political reflections on the situation of impoverished and unrepresented parts of the population in France. Incidents of interpersonal violence are particularly frequent in the narrator's recollections of family life in the past.

The term 'violence' appears for the first time on the second page of the text, when the narrator casts his thoughts back to the father's frequent 'sudden fits of violence' caused by Alzheimer's disease. ${ }^{4}$ From the outset the narrative is therefore doubly inscribed in violence and suffering; firstly, because it confronts the reader immediately and, secondly, because the father's violent illness and his subsequent passing make the journey and thus the narrative possible: 'as soon as he was absent, it became possible for me to undertake this journey or rather this process of a journey's. Already prior to the father's illness the parent's marriage appears as 'marital warfare' ${ }^{6}$ characterised by mutual hatred, and the mother, tempted by divorce, only stays for fear of the husband's 'violent reaction'. ' She too, however, displays violent behaviour, 'perhaps more so than my father' and it is her who the narrator recalls throwing an electric mixer at the father, breaking two of his ribs. ${ }^{8}$ It is the mother's violent behaviour that renders the parents equal in their marriage: interweaving personal memory and theoretical reflection, the narrator here even claims that in the case of the mother's position in the family, feminism, with a focus on women's oppression, would be of little explanatory value.

Against this general background of violent relationships, a particular scene stands out in the narrative of family life. While the memory of other episodes is 'rare, unclear and uncertain', the narrator has one 'precise and haunting' memory, namely that of a scene in which the father returns home drunk after several days of absence, and throws bottle after bottle against the wall. The scene is introduced in a back-and-forth movement between present and past, as the narrator evokes this childhood scene to explain to his mother his recent absence from the father's funeral. The lack of comprehension between mother and son continues, as she is surprised at his recollection of the scene,

${ }^{4}$ Didier Eribon, Retour à Reims [2009] (Paris, Flammarion, 2010), 12. Translations of passages cited from both primary texts are my own.

${ }^{5}$ Eribon (2010: 12-13).

${ }^{6}$ Eribon (2010: 82).

${ }^{7}$ Eribon (2010: 81).

${ }^{8}$ Eribon (2010: 81). 
despite having been 'so little' at the time. ${ }^{9}$ For the narrator, on the other hand, the scene represents an 'indelible trace of a childhood trauma experienced in relation to a "primitive scene".${ }^{10}$ It functions as a founding moment which inaugurated the desire to leave the family behind. The autobiographical recollection, already broken up by the interaction between son and mother in the present of the narrative, then within the same sentence moves into a more theoretical reflection on the scene's interpretation. It is 'not to be understood in psychological or psychoanalytic terms' which would 'dépoliticise ... what in reality is part of the realm of history and (urban) geography, i.e. of the life of social classes'. ${ }^{11}$ This crucial scene of violence thus not only functions as founding moment of the narrator's understanding and fashioning of his own self, but also serves to introduce the sociological epistemic framework of interpretation that is dominant throughout the text.

Interpersonal violence is thus not only seen as having caused an 'indelible trace of a childhood trauma' but it is simultaneously woven into an understanding of structural violence. This structural violence that affects the milieu of the narrator's family has many facets; it appears, for example, in the form of economic disadvantage, a reduced field of opportunities, and political underrepresentation. The narrator summarises the complexity of violence, with reference to James Baldwin's account of his own family, in the following way: 'everything that my father had been, which means everything that I had to reproach him for, everything for which I hated him, had been shaped by the violence of the social world'. ${ }^{12}$ The pages following this formulation, then, trace the father's experience of economic hardship and of war and occupation. The father's personality is identified as 'doubly inscribed in a place and in a time'. ${ }^{13}$ Violent outbursts therefore are part of a spatial and temporal structure; they form part of a geography of violence on the one hand and of a genealogy of violence on the other. The latter element of a temporal succession is presented in terms of the father's history, but then also goes further back to the situation faced by previous generations, equally dominated by war and poverty.

A very similar interpretative framing occurs with regard to the mother as agent of violent behaviour. The aforementioned passage in which the mother is identified as the more physically violent parent is followed by the description of a childhood scene in which the narrator recites a newly learned, short poem in English. The mother reacts with fury, accusing her son of belittling her, as she speaks no foreign language.

\footnotetext{
${ }^{9}$ Eribon (2010: 96).

${ }^{10}$ Eribon (2010: 96).

${ }^{11}$ Eribon (2010: 96).

${ }^{12}$ Eribon (2010: 34).

${ }^{13}$ Eribon (2010: 35).
} 
As with the father, the violent scene leads to the narrator's realisation of a distance between him and the family and is introduced in terms of a founding moment:

From then on, I was conscious of the growing division between the world external to the family home, represented by the college, my studies, by what I learnt, and the space internal to the household. ${ }^{14}$

And here, too, the recollection of a violent act is inserted into a sociological approach seeking to comprehend the behaviour experienced as a child: 'my mother was ... expressing her resentment as a way of admitting that avenues were open to me that, to her, had always been shut off'. ${ }^{15}$ The narrator then insists on the mother's failed attempt to complete an evening class in IT. After weeks of stubborn struggling to keep up, the mother finally 'faced the facts and conceded defeat. She gave up. Bitter and aggrieved. Her last chance had gone by. ${ }^{36}$

The sociological framework deployed by Eribon, often explicit, is here at work implicitly. In numerous places, the text uses the concept of 'self-elimination' or 'auto-elimination' which, for Pierre Bourdieu and Jean-Claude Passeron, is fundamental in explaining the school system's tendency to perpetuate social inequalities. The correlation between an agent's social position and her chances to succeed within secondary and tertiary education is for them not only due to the system's own mechanisms of selection (such as exams, and in France often entry exams), but is based equally on the agent's own disposition to behave in a way that makes failure more likely. In their seminal Reproduction the concept of self-elimination is essential to explaining the workings of the educational system:

Thus, to give a full account of the selection process ... we must take into account not only the explicit judgements of the academic tribunal, but also the convictions by default or suspended sentences which the working classes inflict on themselves by eliminating themselves from the outset or by condemning themselves to eventual elimination ... ${ }^{17}$

The concept of self-selection is an indispensable element in the Bourdieusian account of structural violence, since inequalities are seen as not only being imposed but as requiring the active participation of the agent in order to take effect. The description of the behaviour on which self-elimination is based are echoed by Eribon's description of the family in Retour à Reims:

\footnotetext{
${ }^{14}$ Eribon (2010: 82-3).

${ }^{15}$ Eribon (2010: 83).

${ }^{16}$ Eribon (2010: 84).

${ }^{17}$ Bourdieu \& Passeron (1990a: 92).
} 
Even the negative dispositions and predispositions leading to self-elimination, such as, for example, self-depreciation, devalorization of the School and its sanctions or resigned expectation of failure or exclusion may be understood as unconscious anticipation of the sanctions the School objectively has in store for the dominated classes. $^{18}$

This description fits the mother's failed attempt at education as much as it fits many others of the characters populating Eribon's text. Her violent outburst can thus be seen as part of a reaction of 'self-depreciation'. This immediate embedding of the violent behaviour in approaches to structural violence is indicative of the empathetic character of the text, and its view of different forms of violence as interconnected. However, while the concept of 'self-elimination', in Eribon and in Bourdieu, relies on the active participation of each person in her own exclusion, this is of course not to be read as a facile shifting of responsibility onto the disadvantaged. Instead, the 'negative dispositions and predispositions' quoted above are viewed as operating in an 'unconscious' way and are based on a perception of the world which is crafted by the social position of the individual. For Bourdieu and Passeron, dispositions form a deeply ingrained 'habitus', defined in the following way:

The conditionings associated with a particular class of conditions of existence produce habitus, systems of durable, transposable dispositions, structured structures predisposed to function as structuring structures, that is, as principles which generate and organise practices and representations that can be objectively adapted to their outcomes without presupposing a conscious aiming at ends. ... Objectively 'regulated' and 'regular' without being in any way the product of obedience to rules, they can be collectively orchestrated without being the product of the organising action of a conductor. ${ }^{19}$

Returning to Reims mobilises precisely this understanding of habitus in its portrayal of violence, as the latter is both 'structured' and 'structuring': that is, economically and historically conditioned and generating certain forms of behavior, such as incidents of interpersonal violence. Moreover, in the Bourdieusian conception, the body is a 'fundamental dimension of the habitus', ${ }^{20}$ since it functions as a site of learned dispositions, a 'living memory pad', a depository of automatisms and ways of thinking. Eribon too draws attention to the relationship between the mother's body and her social position: 'the body of a working class woman, when it ages, reveals to everyone the reality of class existence'. ${ }^{21}$ The body appears as the site of an eternal vicious circle:

\footnotetext{
${ }^{18}$ Bourdieu \& Passeron (1990a: 116).

${ }^{19}$ Bourdieu \& Passeron (1990b: 53).

${ }^{20}$ Bourdieu \& Passeron (1990b: 72).

${ }^{21}$ Eribon (2010: 85).
} 
it participates in the mother's self-elimination from the possibility of a white-collar job, it bears the traces of the resulting necessity of factory work, and it is in turn conditioned by the factory to generate the capacity to comply with an 'infernal rhythm' of work..$^{22}$ The narrator notes elsewhere at various points in the text the harm inflicted on working-class bodies through work and the tendency to self-harm expressed, for example, in the conception entertained by his grandmother according to which masculinity is associated with smoking. The narrator draws the conclusion that these circumstances are evidence of 'the naked violence of exploitation'. ${ }^{23}$

While structural violence therefore appears as both impersonal and as perpetuated by those who suffer from it, this does not mean that Eribon's text entertains a conception in which responsibility for violence is attributed to each individual in society in equal measure. In stark terms he wonders whether one can speak of a 'general war waged by society, by the bourgeoisie, by the dominant classes, by an invisible enemyor perhaps by an all too visible one-against the popular classes'. ${ }^{24}$ Eribon is conscious of the risk of defending an approach too similar to conspiracy theories, or an overly functionalist conception of society in which processes of domination act like unstoppable and invisible machines. Nevertheless, he insists that regardless of how the mechanism of social exclusion operates, its result is a constant rejection of the lower strata of society from certain professions and social positions. In the war waged against the dominated, he says, the school system is a battlefield. ${ }^{25}$ This repetition of the vocabulary of war and battle is strikingly reminiscent of the recurrence of violence caused by (historical) war in the first chapters of text dedicated to the family's history. Eribon's account of structural violence, in which interpersonal violence is embedded, thus creates an impression of continuity of violent social conditions across history.

While the mobilisation of sociology aids the effort of empathetic comprehension of violent family relations from which past traumata originated, the text simultaneously describes the protracted process through which the narrator distances himself from the family. As observed above, incidents of interpersonal violence in the family are interpreted by the narrator as giving rise to a desire to escape. While family relations in the past are frequently described in terms of hatred and violence, the narrator's own sentiments towards the family are similarly permeated by hatred and shame. The father's throwing of bottles, for example, instills in him 'a disgust for misery and the refusal of the destiny to which I had been assigned' ${ }^{26}$ Once obliterated by

\footnotetext{
${ }^{22}$ Eribon (2010: 85).

${ }^{23}$ Eribon (2010: 85).

${ }^{24}$ Eribon (2010: 122).

${ }^{25}$ Eribon (2010: 124).

${ }^{26}$ Eribon (2010: 99).
} 
the father's death, hatred gives way to the 'imperious obligation to interrogate my own self', to 'go back in time', and to 'understand'. ${ }^{27}$ A distance is thus established that enables a twofold enquiry: Retour à Reims examines the social roots of the family, but it also describes the narrator's journey of fashioning an alternative habitus. The narrator describes this process as a 'complete re-education', in which he consciously cultivated a taste in art and modified his elocution. The distancing moment that allows the narrator to move between social worlds also enables an 'epistemological break' which makes it possible for the 'class defector' to develop an understanding of his original milieu' ${ }^{28}$ We might conclude that within the narrative of Retour à Reims, the constant shifting between events in family life and sociological interpretation aids the effort of distancing and self-creation, albeit in consideration of the past.

This raises a number of questions. For example, it has been suggested that Eribon's emphasis on the inertia of his family members' social destinies evinces an overly orthodox application of Bourdieu which, in turn, stands in sharp contradiction to the account of Eribon's own escape from his social situation. ${ }^{29}$ The reproach is, in other words, that Eribon's version of Bourdieusian conditioning is so deterministic that it cannot be reconciled with the account of the narrator's exceptional trajectory. While there is not the space here to fully discuss this criticism, one response might be found in Bourdieu's own work, which, although in a very reserved manner, envisages ways in which habitus can indeed be transformed. Such a modification, Bourdieu insists, cannot occur through a simple change in consciousness; 'only a thoroughgoing process of countertraining, involving repeated exercises, can, like an athlete's training, durably transform habitus'. ${ }^{30}$

Another response to such criticisms would be to refer to the incomplete status of the narrator's transformation. At various points, the narrator points us towards its limits, and suggests that the journey back to Reims takes places precisely in the recognition of the need to 'reintegrate in my existential and mental universe the dimensions that I had excluded from it'. ${ }^{31}$ This lingering of the narrator's past can perhaps best be demonstrated through the persistence of moments of violence, even after the original violence that initiated the escape has been abandoned. The process of the transformation of the habitus, for instance, is described as being imbued with violence: 'as any exile, mine implied a form of violence. I did not perceive it since it exerted its hold over me' ${ }^{32}$ This is echoed in the final passage of the text in which the narrator thinks back

\footnotetext{
${ }^{27}$ Eribon (2010: 32).

${ }^{28}$ Eribon (2010: 51).

${ }^{29}$ See, for example: Lane (2012: 127-40).

${ }^{30}$ Bourdieu (2000: 172).

${ }^{31}$ Eribon (2010: 58).

${ }^{32}$ Eribon (2010: 171).
} 
to his father with regret for not having sought communication with him and to have 'allowed the violence of the social world to prevail over myself as it had prevailed over him'. ${ }^{33}$ The coincidence of structural and interpersonal violence, and the inevitability for agents to incorporate into their habitus violent forms of behaviour, thus permeates the text. This theme, as we shall see now, can be found in a much more acute way in Édouard Louis's Histoire de la violence.

\section{HISTOIRE DE LA VIOLENCE}

While Retour à Reims confronts the reader with incidents of interpersonal violence that occur throughout the text and are immediately woven into a wider social analysis, Édouard Louis's auto-fictional Histoire de la violence revolves entirely around one extreme moment of violence and trauma, the narrator's rape by a character named Reda after they meet in the street and share a sexual encounter in the narrator's apartment. ${ }^{34}$ The act of sexual violation itself is surrounded by a protracted scene of violence in which Reda threatens him with a gun and comes close to strangling him. The events leading up to this scene and in its aftermath are alternatingly recounted by the narrator himself, Édouard, and by his sister Clara, whose conversation with her husband the narrator often quotes at length..$^{35}$ Both 'narrators' frequently fill their accounts with reflections on Reda's and Édouard's respective family history; this social framing of an act of interpersonal violence is one element that situates Louis's text in proximity to Eribon's. However, while in Eribon's novel interpersonal violence is only one of a series of phenomena the text explores, The History of Violence is much more exclusively concerned with questions of memory, trauma, and personhood in the context of violence. Nevertheless, the precise meaning of the title is surprisingly ambiguous, in particular because the French noun 'histoire' can be translated as 'history' or as 'story'. ${ }^{36}$ The title could thus be read as a reference to the encounter between Reda and the narrator, to the violence with which Reda's

\footnotetext{
${ }^{33}$ Eribon (2010: 247).

${ }^{34}$ After its publication, the story caused a legal conflict between the author and an individual who recognised himself in Reda. The autobiographical elements of the text (such as the narrator's name, Édouard, or references to identifiable friends such as 'Didier') will not be relevant for the present discussion of the book; instead the focus will be on the representation and narrativisation of violence in the text itself.

${ }^{35}$ The effects of this shift in perspective will be discussed in more detail later.

${ }^{36}$ It should also be borne in mind that the French equivalent for 'rape' is 'viol' and in far greater etymological proximity to 'violence'.
} 
(and Édouard's) family history is impregnated, or to the telling of the violent event and thus to the text itself. In the following, each of these three avenues will be explored.

Like Eribon, Louis frequently uses literary sources as intertexts for the narrator's experience. The rape scene itself, which occurs in the last third of the text, is prefigured by a comparison to William Faulkner's Sanctuary which relates the abduction and rape of Temple Drake. ${ }^{37}$ Louis's narrator identifies with the situation of imprisonment within a violent scene in which Temple finds herself: 'the problem is not to have been forced into a certain behavior ... but to have been forced to remain within the framework of the interaction ... as the violence of imprisonment, of geography were the primary form of violence from which all others derived' ${ }^{38}$ One definition of violence offered by the text is therefore that of complete lack of freedom and power to abandon a violent situation. At other points in the text it appears as the experience of brutality, ${ }^{39}$ and as traumatisation by fear. ${ }^{40}$ Violence is thus a multilayered phenomenon which permeates the entire situation rather than being exclusively associated with its perpetrator.

Violent behaviour of course occurs most starkly in the character Reda, but similarly to the transposition of the narrator's experience to that of another rape survivor, Temple Drake, Reda too is at times depicted indirectly through images and memories. For example, the narrator explains the logic of Reda's behaviour by comparing it to a scene from his childhood in which a cousin called Sylvain caused a 'violent' scene in the classroom, wildly shouting at the teacher and finally leaving through the window. In the narrator's memory, Reda and Sylvain become indistinguishable, for the logic of their action is the same: they seem to act independently of all reason, causing a conflict 'for nothing ... to prove that he was, or was able to embodywhether it's Reda or Sylvain - the most spectacular figure of autonomy. He didn't need to respond to a conflict. He was in the position to create it ... to invent it ... everyone else had to define themselves in relation to him' ${ }^{41}$ In this instance, Louis defines violence not so much as an act or as an experience but as an attitude on the part of the perpetrator. This attitude is characterised by a refusal to engage with reality and produces a sudden eruption of a form of behaviour that negates communication.

At this point the text is close to a phenomenological rather than sociological approach to violence. Jean-Paul Sartre's account, for example, first developed in the late 1940s, similarly understands violence as an attitude that refuses to engage with

\footnotetext{
${ }^{37}$ Faulkner (1933).

${ }^{38}$ Édouard Louis, Histoire de la violence (Paris, Seuil, 2016), 141.

${ }^{39}$ Louis (2016: 15).

${ }^{40}$ Louis (2016: 212).

${ }^{41}$ Louis (2016: 92).
} 
reality and that is 'destructive of real chains of events' and negates temporal successions. ${ }^{42}$ Much like Sylvain/Reda's outburst, it is an instantaneous expression of an attitude that claims for itself 'unconditional freedom' ${ }^{43}$ Louis's text bears a further resemblance to phenomenological approaches to violence in that it is concerned with the relationship or interaction between the perpetrator and the one whose freedom is violated. This is visible, for example, in violent impulses with which the narrator reacts to the events, in his desire to analyse his own behaviour, or in the observation that Reda's own position is less and less free with every choice he makes during the succession of attacks on the narrator.

Unlike Sartre's theory of violence, ${ }^{44}$ however, Louis's text is particularly rich in that it combines the representation of a traumatic event with a consideration of several kinds of structural forms of violence. A long passage is thus dedicated to an account of Reda's father's history who arrived in France as an immigrant from Kabylia. Immigrants are accommodated in inferior conditions, in a hostel whose director is 'violent and tyrannical', formerly part of the French army in the colonies, deemed competent due to his knowledge of the 'migrants' personality, since some of them had fought [against the French] in the former colonies' ${ }^{45}$ Moreover, racism against persons with North-African background is problematised frequently throughout the text, such as in the narrator's account of comments made by the police when he reports the crime. The "violence that [Reda] carried within himself" ${ }^{46}$ therefore appears as inscribed in a wider context of racism and discrimination. The book's title could therefore also be read as referring to a history of violence that begins with the colonial relationship and the violence associated with it, first in the colonies themselves and then through the experience of racism and difficult living conditions in France. Similarly to Eribon, who establishes a genealogy of violence in his own family history, Louis is interested in the origin of Reda's violence and traces its continuity between generations.

Violence in the novel is, however, not limited to Reda and the narrator's encounter with him; similar to Eribon's description of his origins, Louis's narrator has also traversed a process of distancing from his initial habitus and from family relations perceived as violent. Verbal and physical violent attacks which accelerate the narrator's desire to leave the family behind are far more dominant in Louis's previous auto-fictional text

\footnotetext{
${ }^{42}$ Sartre (1992: 173).

${ }^{43}$ Sartre (1992: 175).

${ }^{44}$ At least as far as the Notebooks for an Ethics is concerned. For an account of Sartre's later attempt to integrate a theory of interpersonal and structural violence, see Mueller (2018).

${ }^{45}$ Louis (2016: 65).

${ }^{46}$ Louis (2016: 66).
} 
En finir avec Eddy Bellegueule [The End of Eddy]. ${ }^{47}$ And in Histoire de la violence, too, we find a form of violence in the narrator's recollection in the family's non-acceptance of his homosexuality. ${ }^{48}$ At the same time, the later text is striking in its particular effort to also reveal the structural violence affecting the family. This is evident in a long passage dedicated to the mother's work as a carer for elderly people, which frequently exposes her to violent outbursts. Similarly, the work as a truck driver of the narrator's sister's husband is described in detail, with an emphasis on the lack of interest in the foreign places to which his work takes him: on the road he sees nothing but always the same road signs for cities which 'he never visits anyway, lacking time, lacking everything ... he has neither the possibility nor the desire; no possibility and therefore no desire ... . ${ }^{49}$ With less explicit sociological vocabulary than Retour à Reims, the novel analyses the social position of the narrator's brother-in-law in very similar terms: structural violence acts through a diminished set of possibilities, and a social destiny is fulfilled with the help of a process of auto-elimination, or here lack of desire.

The portrayal of interpersonal violence within a wider framework of social relations characterised by interpersonal violence is, however, only one aspect of the text's treatment of the traumatic event at its centre. Examining the representation of the narrator's personal trauma is essential for an understanding of the particular role played by the narrative form. In the description of the narrator's reaction to the scene with Reda, references to a sense of loss of meaning, or unreality, occur with striking frequency. Already, whilst being threatened by Reda, the narrator has a distorted sense of time, which will last throughout his conversation with the police on the following day ${ }^{50}$ Whilst speaking to police officers, he recalls having said things 'that

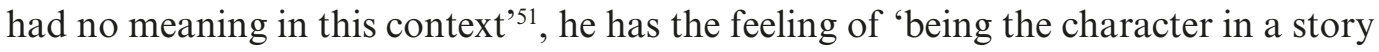
that wasn't mine'. ${ }^{52}$ While the narrator is affected by a 'mad desire to speak', ${ }^{53}$ the traumatic moment simultaneously causes language to lose its meaning. The rape itself is thus perceived as proof that there can be a state in which human beings function without language, ${ }^{54}$ and in a conversation with his friend certain words change their meaning and instead signify elements relating to Reda..$^{55}$ If the violation is described as an act of 'killing', ${ }^{56}$ it seems that one of the elements it destroys is the narrator's

\footnotetext{
${ }^{47}$ See, for example: Louis $(2014: 43,49)$.

${ }^{48}$ Louis (2016: 83-4).

${ }^{49}$ Louis (2016: 156).

${ }^{50}$ Louis (2016: 146).

${ }^{51}$ Louis (2016: 50).

${ }^{52}$ Louis (2016: 31).

${ }^{53}$ Louis (2016: 30).

${ }^{54}$ Louis (2016: 123).

${ }^{55}$ Louis (2016: 177).

${ }^{56}$ Louis (2016: 124).
} 
capacity to use language and be in control of his own 'story' and hence sense of self. Accordingly, the narrator's memory is constantly questioned, often seen as unreliable and threatened by the superposition of the stories that others have shaped. This is the case, for example, when the police's questioning 'imposes a certain form on my narrative', thereby encouraging some memories and relegating others to oblivion, demonstrating to the narrator that 'one can only remember by forgetting'. ${ }^{57}$

The narrator's identity, memory, and testimony of his own experience therefore appear as precarious and constantly threatened by the narrative of the events that others tend to form. In this context, the text's use of perspective is particularly noteworthy. The reader is at times directly addressed by the first-person narrator. At other times, the narrator quotes his sister, who in turn reports Édouard's experience to her husband, having been told about it by her brother, who in turn overhears his relatives' conversation. In both cases the narrator (Édouard) frequently interjects italicised passages that form a comment on what has previously been related by Clara. The twofold narrative structure using the sister as second-hand narrator is further complicated by the introduction of a third level, when Édouard quotes his sister quoting a comment made, for example, by their mother. The narrator also frequently quotes himself via his sister. In the first instance, the effect of this structure is to reinforce the sense of Édouard's weakened ownership of his own narrative. The narrator's lack of agency is emphasised by his transformation from 'I' to 'he', mainly at the hands of the sister, ${ }^{58}$ but at one point also through referring to himself in the third person singular..$^{59}$

Gérard Genette was one of the first to theorise such procedures as cases of 'metalepsis', designating any 'taking hold of (telling) by changing level', ${ }^{60}$ and transgressions of a text's relationship between narrator and narratee (the implied person whom the narrator is addressing). Metalepsis often has a comical effect, but is for Genette also unsettling, since it bears the 'unacceptable and insistent hypothesis, that the extradiegetic [that which is external to the narrative] is perhaps always diegetic [part of the narrative], and that the narrator and his narratees - you and I-belong to some narrative'. ${ }^{11}$ While this comment particularly fits metaleptic transgressions in which the narrator suddenly addresses the reader, Histoire de la violence operates through a reversal or a 'downward movement' in which the narrator himself becomes the object of the narration by one of the characters (the sister) while the position of the narratee shifts to the sister's husband.

\footnotetext{
${ }^{57}$ Louis (2016: 93).

${ }^{58}$ Louis (2016: 21).

${ }^{59}$ Louis (2016: 209).

${ }^{60}$ Genette (1980: 236).

${ }^{61}$ Genette (1980: 236).
} 
Metalepsis is a thriving field of research and Genette's theory has been redefined in a multitude of ways. Debra Malina's recent contribution in Breaking the Frame might be helpful in our understanding of the relationship between narrative and violence in Louis. Malina addresses the circumstance that postmodernist literary theory has long assumed that an overly linear and teleological narrative exerts a certain kind of violence on the reader. ${ }^{62}$ She shifts the attention away from this view and instead points towards the opposite, namely the violence inherent in metaleptic ruptures in the order of a text. Malina further notes that 'because it traverses an ontological hierarchy, metalepsis has the power to endow subjects with greater or lesser degrees of "reality" - in effect, to promote them into subjectivity and demote them from it' ${ }^{63}$ Assuming with Malina that different narrative levels are thus organised into a hierarchy of degrees of reality, we find that Histoire de la violence deploys narrative structure in order to de-realise the narrator. Following further Malina's assumption that metalepsis is a tool mobilised to express violence, rather than to break up a violently teleological narrative, we are led to conclude that the narrative form of the text in fact stages the violent experience which is at its centre. It is only coherent with the ubiquity of violence portrayed in Louis's text that the narrative itself should be marked by it.

In the hands of the narrator, however, the relinquishing of his own story to one of his characters appears as only a temporary strategy in an attempt to regain lost subjectivity. All along the text, the narrator frequently comments on Clara's words through the medium of italicised passages, at times contradicting her account. Towards the end of the text, after the recounting of the rape scene itself, Édouard repeatedly tells the reader that he stops listening to Clara, 'whose digressions have become tiring' ${ }^{\prime 64}$. It seems thus as though towards the end of the novel the decomposition of the narrator's subjectivity gives way to an attempt to construct a 'form of memory that does not simply repeat the past ... but one that would allow me to unravel the past, simultaneously amplifying and destroying it'. ${ }^{65}$ As in Eribon's case, this project seems to involve a multiplicity of strategies, in which narrative experimentation and sociological interpretation both play a crucial role.

\footnotetext{
${ }^{62}$ Malina (2002: 3).

${ }^{63}$ Malina (2002: 4).

${ }^{64}$ Louis (2016: 187).

${ }^{65}$ Louis (2016: 180).
} 


\section{REFERENCES}

Bartlett, Neil (2017), 'The End of Eddy by Édouard Louis. Review-A Childhood in Hell', The Guardian, 1 February.

https://www.theguardian.com/books/2017/feb/01/the-end-of-eddy-by-edouard-louis-review

Bourdieu, Pierre, (2000), Pascalian Meditations [1997], trans. Richard Nice (Stanford, CA, Stanford University Press).

Bourdieu, Pierre \& Passeron, Jean-Claude (1990a), Reproduction in Education, Society and Culture [1970], trans. Richard Nice (London, Sage).

Bourdieu, Pierre \& Passeron, Jean-Claude (1990b), The Logic of Practice [1980], trans. Richard Nice (Standford, CA, Stanford University Press).

Eribon, Didier (2010), Retour à Reims [2009] (Paris, Flammarion).

Faulkner, William (1933), Sanctuary (London, Jonathan Cape).

Genette, Gérard (1980), Narrative Discourse, An Essay in Method [1972], trans. Jane Lewin (Ithaca, NY, Cornell University Press).

Lane, Jeremy (2012), 'From "Amor Fati" to "disgust": Affect, Habitus, and Class Identity in Didier Eribon's Retour à Reims', French Cultural Studies, 23(127): 127-40. https://doi.org/10.1177/0957155812436533

Louis, Édouard, (2014), En finir avec Eddy Bellegueule (Paris. Seuil).

Louis, Édouard (2016), Histoire de la violence (Paris, Seuil).

Malina, Debra (2002), Breaking the Frame: Metalepsis and the Construction of the Subject (Columbus, $\mathrm{OH}$, Ohio State University Press).

Mueller, Marieke (2018), 'Sartre's later work: Towards a Notion of Institutional Violence', in The Meanings of Violence, edited by Gavin Rae \& Emma Ingala (London, Routledge), 129-47.

Sartre, Jean-Paul (1992), Notebooks for an Ethics, trans. David Pellauer (Chicago, IL, and London, Chicago University Press).

To cite the article: Marieke Mueller (2020), 'Violence and narrative: structural and interpersonal violence in contemporary French literature', Journal of the British Academy, 8(s3): 155-169.

DOI https://doi.org/10.5871/jba/008s3.155

Journal of the British Academy (ISSN 2052-7217) is published by

The British Academy, 10-11 Carlton House Terrace, London, SW1Y 5AH

www.thebritishacademy.ac.uk 
